\title{
NANCY NATURAL RADIOCARBON MEASUREMENTS II
}

\author{
B. HASSKO, B. GUILLET,* and R. COPPENS
}

Centre de Recherches Radiogéologiques, Nancy, Vandoeuvre, $54 \mathrm{~F}$

The following list includes a selected number of measurements made during 1967-1968 in the Natural Radiocarbon Laboratory of the Centre de Recherches Radiogéologiques de Nancy. This list is a continuation of Nancy Natural Radiocarbon Measurements I (Radiocarbon, 1968, v. 10, p. 119-123). The dating method, counting technique, and equipment are described in that list. All measurements were made in a proportional counter with a capacity of $1.16 \mathrm{~L}$, normally filled with $\mathrm{CO}_{2}$ under a pressure of $736 \mathrm{~mm} \mathrm{Hg}$. Ages are calculated using a $\mathrm{C}^{14}$ half-life of 5568 yrs with 1950 as reference yr. Modern standard used following samples $\mathrm{Ny}-118$ is $95 \%$ of NBS oxalic acid activity. The $\delta \mathrm{C}^{14}$ mentioned later in the date list are calculated according to Broecker and Olson (1959).

\section{ACKNOWLEDGMENTS}

We thank Mr. R. Jaegy who made the proportional counters and maintained the electronic operation.

\section{SAMPLE DESCRIPTIONS}

I. GEOLOGIC AND ARCHAEOLOGIC SAMPLES

\section{Ny-97. Mas Neuf No. 130}

Age determination of Post-Würmian layer of Camargue area, region of Saint-Gilles ( $43^{\circ} 41^{\prime} \mathrm{N}$ Lat, $4^{\circ} 26^{\prime} \mathrm{E}$ Long). Peat interbedded in gray marshy clay at $-9 \mathrm{~m}$ drilling core Mas Neuf No. 130. Coll. and subm. 1967 by A. Bonnet, Lab. Géol. Quat. C.N.R.S., Paris. Comment: dating of peat horizon has contributed to understanding of precise stratigraphy of Camargue (Bonnet, 1966) which is $10 \mathrm{~km}$ from "Saint-Gilles series" (Radiocarbon, 1968, v. 10, p. 122).

\section{Ny-100. Gizeux, France}

$10,095 \pm 420$

Humified black compact peat lying on local alluvial sand in calcareous Turaniam neighborhood. In SW Parisian Basin near Saumur $\left(47^{\circ}\right.$ $23^{\prime}$ N Lat, $2^{\circ} 06^{\prime}$ W Long). Coll. and subm. 1967 by N. Planchais, Centre de Pédologie Biol., Nancy, Vandoeuvre. Comment: sample depth was 110 to $120 \mathrm{~cm}$. Age agrees well with pollen analysis (Pre-Boreal) of $\mathrm{N}$. Planchais (1967).

\section{Manosque, Basses-Alpes series}

Two human bones in grave from choir of old Observantin church NE of Manosque City (43 $52^{\prime}$ N Lat, $4^{\circ} 47^{\prime}$ E Long). Coll. 1967 at request of M. Auber Millot by M. Sczaniel and subm. by J. Cases, C.N.R.S., Nancy, Vandoeuvre.

* Centre de Pédologie Biologique, Nancy, Vandoeuvre 
Ny-81. Human bone, upper layer

Modern

Ny-82. Human bone, lower layer

Modern

Comment: should date to time of French Revolution (ca. A.D. 1790).

\section{Foix, rue Lafaurie, Ariège series}

Wooden coal found in remains of forge during excavation for foundation of youth home of Foix City $\left(42^{\circ} 57^{\prime} \mathrm{N}\right.$ Lat, $0^{\circ} 80^{\prime} \mathrm{W}$ Long). Samples coll. and subm. 1967 by P. Blazy, Fac. Sci., Univ. de Nancy.

Ny-93. Wooden coal, -1 m

Ny-95. Wooden coal, $-1.50 \mathrm{~m}$

Noment: all work to be publ. by turelles" (Archeol. Cong.).

Ny-113. Tronville-en-Barrois, Meuse

Modern

Human bone, radius, cubitus, and left hand surrounded by thin calcareous cover from rock chalk quarry of abandoned mill in Tronvilleen-Barrois ( $48^{\circ} 43^{\prime} \mathrm{N}$ Lat, $5^{\circ} 16^{\prime}$ E Long). Coll. and subm. by Dr. Petiet, Nancy.

Ny-83. Kolle, Tchad

$1460 \pm 220$

A.D. 490

Charcoal with pieces of human bone and pottery in eolian sand of ancient dune sealed by lacustrian diatomite deposit several $\mathrm{m}$ high, at Kolle site, $\mathrm{N}$ of Tchad ( $16^{\circ} 08^{\prime} \mathrm{N}$ Lat, 19 ${ }^{\circ} 0^{\prime} \mathrm{E}$ Long). Coll. 1966 and subm. 1967 by Y. Coppens, Mus. Hist. Nat., Paris.

\section{SOIL SAMPLES}

This list contains some dates related to migration of organic matter in podzol. All dated horizons have been coll., physically and chemically pretreated, and subm. by B. Guillet. Locality and pedological type of podzols whose horizons $A_{0}, A_{1}$ or $B h$ are dated, will be given under each heading. Fractionation of humic acids and fulvic acids from several $\mathrm{Bh}$ horizons was made after previous separation of roots and unhumified organic debris from soil samples by heavy liquid.

\section{Barembach iron-humus podzol pit series}

Iron podzol (humod) in Vosges at Barembach near Schirmeck (BasRhin) (48 $27^{\prime} 51^{\prime \prime} \mathrm{N}$ Lat, $4^{\circ} 56^{\prime} 16^{\prime \prime}$ E Long). Podzol was developed on Kagenfels hercynian acid granite, under ancient fir wood with beech as shown by palynological study (Guillet, 1968). All samples from same pit.

Ny-90. Barembach raw humus, upper layer

Modern

Podzol raw humus horizon, $10 \mathrm{~cm}$ thick. Dated from unhumified layer, $8 \mathrm{~cm}$ above $\mathrm{A}_{1}$ epipeclon. Comment: see $\mathrm{Ny}-92$. 
Ny-92. Barembach raw humus, lower layer

Modern

Humified layer just above $A_{1}$ epipedon (from 0 to $2 \mathrm{~cm}$ ). Comment: it is impossible to date raw humus due to contamination of little roots of Calluna and Graminées. However, palynological study shows raw humus is ca. $200 \mathrm{yr}$ old.

\section{Ny-84. Barembach $A_{1}$ horizon}

A.D. 1660

$290 \pm 160$

From $10 \mathrm{~cm}$ under top of $A_{1}$ epipedon. Removal of roots made after drying at $105^{\circ} \mathrm{C}$ followed by floating of roots by water stream. Almost root-free material is decanted through $0.5 \mathrm{~mm}$ mesh sieve; carbon content of resulting fraction is $6 \%$. Comment: younger than expected. Perhaps root removal is not efficient enough.

\section{Ny-77. Barembach Bh}

A.D. 1150

$800 \pm 170$

Iron-humus pan, 45 to $50 \mathrm{~cm}$ below top of $\mathrm{A}_{1}$ epipedon. To prevent contamination by roots, only fraction over $2 \mathrm{~mm}$ mesh was burnt and dated; its carbon content was $0.7 \%$. Comment: palynologic and pedologic studies (Guillet, 1968) show that acidification and podzolization of this soil are older than this date.

\section{Ny-96. Barembach Bh, humic acid}

$940 \pm 135$

Separation of Bh sample by solution of Bromoform-Alcohol (density 2). Extraction of humic and fulvic acids from heavier part of material by $1 \%$ sodium pyrophosphate (Duchaufour and Jacquin, 1963). Humic acids flocculate and fulvic acids remain in solution upon addition of $\mathrm{HCl}$ until $\mathrm{pH}$ 1. Humic acids are centrifuged, dried at $105^{\circ} \mathrm{C}$, and burnt. Comment: age of humic acids is statistically indistinguishable from $\mathrm{Ny}-77$.

\section{Ny-94. Barembach Bh, fulvic acids}

Modern

Oxidation by sulfo-chromic solution of fulvic acid solution. Comment: since fulvic acids are generally considered younger than humic acids in iron-humus pan of podzols, a modern age was not expected. Contamination by alcohol from heavy solution is possible.

\section{Saint-Gorgon iron-humus podzol pit series}

Saint-Gorgon iron-humus podzol is near Rambervillers (Vosges) in Saint-Gorgon forest $\left(48^{\circ} 19^{\prime} 26^{\prime \prime} \mathrm{N}\right.$ Lat, $\left.4^{\circ} 19^{\prime} 05^{\prime \prime} \mathrm{E} \mathrm{Long}\right)$. It was formed on ancient sandy alluvions by acidific vegetation with Calluna; Calluna has now disappeared and no raw humus is found on this soil (Guillet, 1968).

Ny-103. Saint-Gorgon $A_{1}$, epipedon A.D. 1370 $580 \pm 170$

$A_{1}$ epipedon sample at $10 \mathrm{~cm}$ below surface. Roots removed from pounded material by drying at $105^{\circ} \mathrm{C}$ and floating in water. Residual sample with $5 \%$ carbon content was burnt. Comment: this epipedon date is oldest reported in this list. 


\section{Ny-99. Saint-Gorgon Bh}

$1010 \pm 125$

Bh horizon sample 55 to $63 \mathrm{~cm}$ below surface. Pretreated as Ny-103. Comment: according to palynological study of podzol profile, older date was expected.

\section{Ny-111. Saint-Gorgon Bh, humic acids}

$610 \pm 80$

Humic acids from heavier part of Bh material. Separation was made with density 1.8 heavy-liquid of zinc chloride. Lighter part is also dated ( $\mathrm{Ny}$-108). Extraction and flocculation of humic acids made as in $\mathrm{Ny}-96$. Comment: much younger age of humic acids in relation with age of $\mathrm{Bh}$ $\mathrm{Ny}$-99 cannot be explained.

Ny-114. Saint-Gorgon Bh, fulvic acids

Modern

Same oxidation as Ny-94. Comment: in this podzol, fulvic acids are considerably younger than humic acids.

\section{Ny-108. Saint-Gorgon Bh, lighter part}

Modern

Combustion of lighter part resulting from separation by heavy liquid. Comment: mainly formed by roots and organic debris, this fraction has same $\mathrm{C}^{14}$ activity as fulvic acids $\mathrm{Ny}-114$, i.e., $99.5 \%$ of $\mathrm{C}^{14} \bmod -$ ern standard activity.

\section{Sainte-Hélène iron-humus podzol pit series}

Podzol near St-Gorgon podzol in same forest, at Ste-Hélène $\left(48^{\circ} 18^{\prime}\right.$ $34^{\prime \prime} \mathrm{N}$ Lat, $4^{\circ} 20^{\prime} 05^{\prime \prime} \mathrm{E}$ Long). Iron-humus podzol in colluvial sandy deposits under pine-grove with Calluna and Myrtillus. At $8 \mathrm{~cm}$, raw humus lies on soil.

\section{Ny-104. Ste-Hélène $A_{1}$}

$160 \pm 90$

$A_{1}$ epipedon at $10 \mathrm{~cm}$ below top of this horizon. Same pretreatment as $\mathrm{Ny}-84$. Comment: an age, younger than $\mathrm{Ny}-103$, was expected.

\section{Ny-102. Ste-Hélène}

$$
1760 \pm 110
$$

Sample pretreated as other Bh pans. Comment: palynologic study of this iron-humus podzol shows same pollen profile as Saint-Gorgon podzol, yet age, is statistically distinguishable from $\mathrm{Ny}-99$.

\section{Ny-98. Route de Liaucourt podzol Bh}

Iron-humus podzol on granitic coarse sands near Gerardmer, Vosges ( $48^{\circ} 03^{\prime} 18^{\prime \prime} \mathrm{N}$ Lat, $4^{\circ} 33^{\prime} \mathrm{E}$ Long). Organic matter does not form continuous layer but is diffused down through B horizon. However, upper part of $\mathrm{B}$ horizon, $\mathrm{Bh}$, is darker than lower part; carbon content is $4 \%$ From 50 to $55 \mathrm{~cm}$ below soil surface in Bh horizon. Comment: oldest of all podzol Bh in Vosges Mts. 


\section{Le Temple pit series}

Sandpit with 2 independent B layers lying in Landes near Bordeaux at Le Temple (44 $52^{\prime} \mathrm{N}$ Lat, $3^{\circ} 22^{\prime} \mathrm{W}$ Long). Coll. 1967 by F. Jacquin, Fac. Sci., Nancy; subm. and pretreated 1968 by B. Guillet. Lower B layer is hardpan at $120 \mathrm{~cm}$ below soil surface; covered by sandy material on which was developed a well defined iron-humus podzol with ironhumus pan at $70 \mathrm{~cm}$ below soil surface. Podzol iron-humus pan should have been in balance, for a few centuries at least, with landaise pine forest and is called: Le Temple 1. Hardpan is considered fossil and called: Le Temple 2. Iron-humus pan of Le Temple 1 with $0.9 \%$ carbon content and hardpan of Le Temple 2 with $1.1 \%$ carbon content were dated first from a root-free whole $B$ sample, and also from fulvic and humic acids fractions extracted as follows: from each pan layer, a first extraction and separation of humic acids and fulvic acids by sodium pyrophosphate and $\mathrm{HCl}$ as $\mathrm{Ny}-96$. Fulvic acids and humic acids are separately dated, carbon weight permitting. Then, a second extraction of humic and fulvic acids by $\mathrm{N} / 10 \mathrm{NaOH}$ was made from material following extraction by sodium pyrophosphate. A small quantity of carbon was extracted and the fulvic acids and humic acids were dated together.

\section{Ny-105. Le Temple 1, iron-humus pans, $70 \mathrm{~cm}$ \\ Ny-115. Le Temple 1, pyrophosphate extr., humic acids \\ Ny-116. Le Temple 1, pyrophosphate extr., fulvic acids \\ $2550 \pm 180$ \\ 600 B.C. \\ $2500 \pm 140$ \\ 550 в.c. \\ $1660 \pm 110$ A.D. 290}

Ny-117. Le Temple 1, NaOH extr., fulvic and humic acids
Modern

Comment for Le Temple 1: similar ages of organic matter of ironhumus Bh podzol in Landes were publ. elsewhere (Delibrias et al., 1966). Fulvic acids are younger than humic acids while both fulvic and humic acids are quite modern.

Ny-101. Le Temple 2, hardpan $120 \mathrm{~cm}$

$4520 \pm 210$

Ny-118. Le Temple 2, pyrophosphate extr., humic acids

2570 B.c.

$2850 \pm 110$

900 B.C.

Ny-120. Le Temple 2, pyrophosphate extr., fulvic and humic acids

$2000 \pm 120$

50 B.C.

Fulvic acids fraction small, therefore, fulvic and humic acids are oxidized together with sulfo-chromic solution.

Ny-122. Le Temple 2, $\mathrm{NaOH}$ extr., fulvic and humic acids

Modern $\delta \mathbf{C}^{14}=+\mathbf{1 0 6} / \%$

Comment for Le Temple 2: hardpan is one of oldest we know, and confirms fossil state of ancient buried podzol. 
General Comment for podzols: in Landes, hardpan and iron-humus podzol ages are similar to those publ. either about English podzols (Godwin and Willis, 1964) or about French podzols from the Landes (Delibrias et al., 1966). Vosgian podzols give Bh organic matter younger than those in Landes, but ages can be compared with German podzol (Scharpenseel et al., 1968), however $A_{1}$ ages are younger. Comparisons between pollen migration and humus migration in Barembach and Saint-Gorgon podzols led Guillet (1968) to think that $\mathrm{C}^{14}$ age dates are minimum, and that age of podzol formation is 2 or 3 times older than $\mathrm{C}^{14}$ age, as stated by Scharpenseel et al. (1968).

Date lists:

\section{REFERENCFS}

Bonn

Cambridge VI

Lamont V

Scharpenseel, Pietig, and Tamers, 1968

Nancy I

Godwin and Willis, 1964

Broecker and Olson, 1959

Coppens, Durand, and Guillet, 1968

Bonnet, A., 1966, Structure de la Camargue entre Arles, Beaucaire, et Saint-Gilles-duGard: Soc. Géol. de France Comptes-rendus, v. 7, p. 258-259.

Brocker, W. S. and Olson, E. A., 1959, Lamont radiocarbon measurements VI: Am. Jour. Sci. Radiocarbon Suppl., v. 1, p. 111-132.

Coppens, R., Durand, G. L. A., and Guillet, B., 1968, Nancy natural radiocarbon measurements I: Radiocarbon, v. 10, p. 119-123.

Delibrias, G., Dutil, P., and Juste, C., 1966, Premiers résultats de mesure d'age de la matière organique de l'horizon d'accumulation des podzols humiques développés sur le sable des Landes: Acad. Sci. [Paris] Comptes-rendus, v. 263, no. 18, p. 13001302.

Duchaufour, Ph. and Jacquin, F., 1963, Recherche d'une méthode d'extraction et de fractionnement des composés humiques contrôlée par électrophorèse: Annales Agronom., v. 14, p. 885-918.

Godwin, H. and Willis, E. H., 1964, Cambridge University natural radiocarbon measurements VI: Radiocarbon, v. 6, p. 116-137.

Guillet, B., 1968, Essai de détermination de l'age de deux podzols vosgiens par la palynologie: Oecologia Plantarum, v. 3, p. 101-119.

Planchais, N., 1967, Analyse pollinique de la tourbière de Gizeux (Indre-et-Loire) et étude du chêne-vert à l'Optimum Climatique: Pollen et Spores, v. 9, no. 3, p. 505520 .

Scharpenseel, H. W., Pietig, F., and Tamers, M. H., 1968, Bonn radiocarbon measurements I: Radiocarbon, v. 10, p. 8-28. 